MAKALAH

\title{
WESTERNISASI DAN CARA MELESTARIKAN IDENTITAS NASIONAL
}

Diajukan untuk memenuuhi tugas Mata Kuliah Sejarah Eropa (Kode 872010001420)

Dosen Pengampu :

Dr. Mohamad Zaenal Arifin Anis, M.Hum

Mansyur, S.Pd., M.Hum

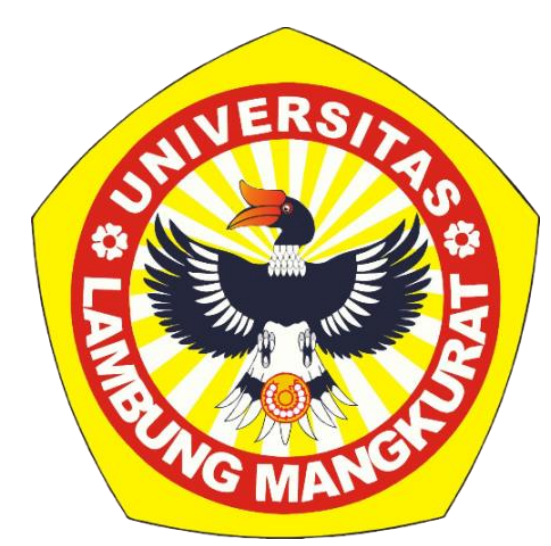

Disusun Oleh : Kelompok 5 (A2)

$\begin{array}{ll}\text { Aulia } & 2010111320010 \\ \text { Muhammad Aminullah } & 2010111310004 \\ \text { Yeni Lestari } & 2010111220013\end{array}$

PROGRAM STUDI PENDIDIKAN SEJARAH

JURUSAN PENDIDIKAN ILMU PENGETAHUAN SOSIAL

FAKULTAS KEGURUAN DAN ILMU PENDIDIKAN

UNIVERSITAS LAMBUNG MANGKURAT

BANJARMASIN

2021 


\section{KATA PENGANTAR}

Puji syukur atas kehadirat Allah SWT yang telah memberikan rahmat dan hidayahnya sehingga kami dapat menyelesaikan tugas makalah yang berjudul Westernisasi dan cara Melestarikan Identitas Nasioanl ini tepat pada waktunya.

Adapun tujuan dari makalah ini adalah untuk memenuhi tugas dari Bapak Dr. Mohamad Zaenal Arifin Anis, M.Hum dan Bapak Mansyur, S.Pd., M.Hum. Pada mata kuliah Sejarah Eropa. Selain itu, makalah ini bertujuan untuk menambah wawasan tentang Negara Menurut Pemikiran Rousseau bagi para pembaca dan juga penulis.

Kami mengucapkan terimakasih kepada Bapak Dr. Mohamad Zaenal Arifin Anis, M.Hum dan Bapak Mansyur, S.Pd., M.Hum. selaku mata kuliah Sejarah Eropa yang telah memberikan tugas ini sehingga dapat menambah pengetahuan dan wawasan yang sesuai dengan bidang yang kami tekuni.

Banjarmasin 12 Mei 2021

Kelompok 5 


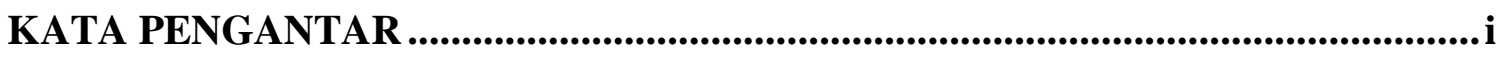

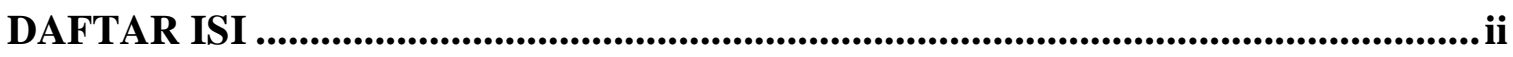

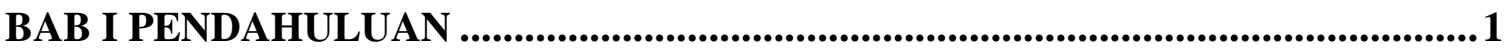

A. Latar Belakang Masalah .........................................................................................1

B. Rumusan Masalah .............................................................................1

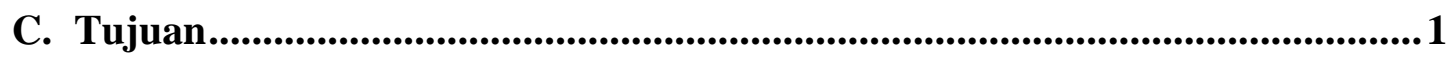

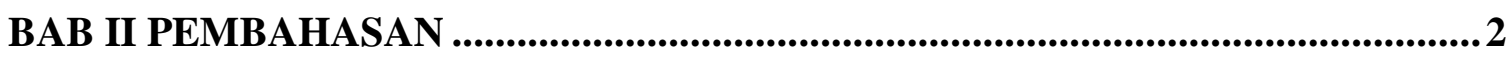

A. Westernisasi Dalam Kehidupan Masyarakat ..........................................................2

B. Melestarikan Identitas Nasional .................................................................4

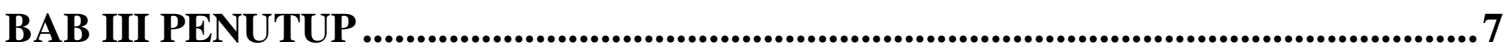

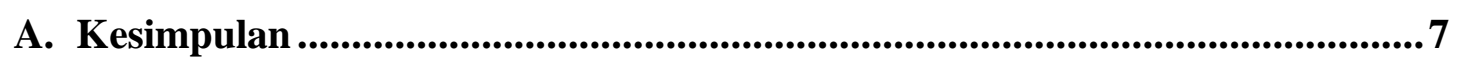

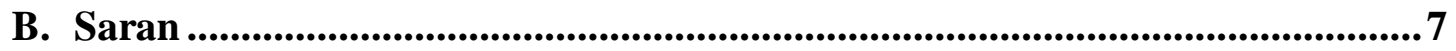

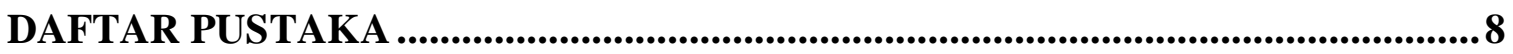




\section{BAB I}

\section{PENDAHULUAN}

\section{A. Latar Belakang Masalah}

Pengaruh budaya Barat atau yang dikenal dengan istilah "Westernisasi" telah terlihat jelas dewasa ini. Dimana pola kehidupan masyarakat semakin hari semakin hanyut dalam pola modernis dengan berkiblat kepada sistem budaya Barat (Westernisasi), yang dianggap sebagai kebudayaan modern atau sebagai alternatif budaya masa kini. Dan ini terjadi di kalangan remaja, yang begitu rapuh menerima peradaban-peradaban asing sebagai suatu kebanggaan. Pengaruh budaya ini memang tidak dapat dihindari di zaman yang semakin canggih ini, proses interaksi antar bangsabangsa di dunia melalui pertukaran pelajar atau mahasiswa kunjungan wisatawan dan program lainnya semakin meningkat hari demi hari. Sedangkan proteksi untuk menghadapi arus pengaruh budaya ini sangat lemah di masyarakat, sehingga merakapun mulai meninggalkan jati diri sebagai bangsa yang berbudi luhur, tanpa mengenal batasbatas ajaran agama dan moralitas budaya.

\section{B. Rumusan Masalah}

1. Bagaimana westernisasi dalam masyarakat?

2. Bagaiamana cara melestarikan identitas nasional?

\section{Tujuan}

1. Mengetahui bagaimanana westernisasi dalam masyarakat.

2. Mengatahui bagaiamana cara melestarikan identitas nasional. 


\section{BAB II}

\section{PEMBAHASAN}

\section{A. Westernisasi Dalam Kehidupan Masyarakat}

Kata Westernisasi secara harfiah bermakna "membaratkan" berasal dari kata westernize. Keadaan meniru-niru yang terdapat dalam dunia Barat. Atau dengan kata lain westernisasi menjadikan kita orang Barat yang berkebudayaan Barat. Koentjaraninggrat mengatakan westernisasi itu adalah usaha meniru gaya hidup orang Barat secara berlebihan, meniru dari segala segi kehidupan baik dari segi fashion, tingkah laku, budaya dan lainnya. di sisi lain, sikap para peniru yang merendahkan adat, budaya dan bahasa nasional.

Jadi, westernisasi merupakan perbuatan pemujaan yang berlebihan terhadap Barat dengan cara mengadopsi secara keseluruhan pola kehidupan mereka tanpa ada filter yang menyaringnya. Pola adopsi ini tidak saja terjadi secara objektif, namun bisa terjadi secara subjektif yaitu interaksi yang lahir dari ide suatu individu, masyarakat atau bangsa untuk mengambil dan meniru cara-cara orang Barat dalam berbagai demensi untuk suatu tujuan ke arah kemajuan.

Proses imperialisme dan kolonialime dalam waktu yang panjang terjadi di Indonesia memberikan dampak yang luas dalam kehidupan masyarakat. Diantara dampak itu adalah terjadinya westernisasi dalam segala segi kehidupan masyarkat Indonesia.

Dalam lembaran sejarah Indonesia tidak pernah dijelaskan secara pasti sejak kapan proses westernisasi ini terjadi. Sebagian para pakar sejarah Islam mengatakan bahwa proses westernisasi ini terjadi sejak dimulainya kolonialisme dan imperialisme di Indonesia dan dunia Islam lainnya pada abad 19 masehi. Hal dapat dibenarkan karena pengaruh secara langsung dapat dilakukan oleh Barat terhadap masyarakat Indonesia terjadi di era itu.

Sementara itu, pengaruh westernisasi dikalangan masyarakat muslim secara umum muncul dalam dua periode: Pertama, westernisasi muncul ketika Islam di bawah kepemimpinan Abbasyiah II. Hal tersebut disebabkan bangsa Arab mulai memasuki era 
kemunduran, baik di bidang politik maupun ekonomi. Pengaruh itu terlihat jelas pada era ini dengan pergeseran nilai-nilai Islam akibat takluknya wilayah-wilayah Islam. Selain itu, dapat ditandai dengan hilangnya sikap zuhud dalam tubuh masyarakat Islam. Kedua, westernisasi muncul di masa kepemimpinan Turki Usmani ketika terjadi perpecahan di antara khalifah Islam yang memberi peluang modernisasi westernisasi.

Disamping dua periode di atas, pada dasarnya proses westernisasi sudah lama terjadi melalui interaksi sarjana Barat dengan sarjana Islam di perguruan-perguruan Arab di Andalusia dan wilayah-wilayah Islam lainnya. Proses tersebut terjadi melalui penyerapan pendapat-pendapat pemikir Barat atau tenaga westernisasi.

Faktor yang mempengaruhi timbulnya westernisasi di Indonesia secara umum disebabkan oleh faktor informasi dan yang datangnya melalui audio visual, disamping itu juga melalui kontak sosial terutama sekali di daerah-daerah pusat industri dan kepariwisataan. Kemajuan-kemajuan yang sangat besar dalam bidang komunikasi menyongsong timbulnya era informasi secara global, artinya tidak ada satu bangsapun di dunia ini menutup diri dari era informasi.

Kemudian dari pada itu, tuntutan perkembagan zaman yang menghendaki pola kehidupan yang lebih maju dari segala segi kehidupan, mengakibatkan perubahanperubahan di sektor ekonomi dan sistem sosial budaya masyarakat. Namun, yang sangat mengkhawatirkan adalah perubahan sistem sosial budaya ini cenderung ke barat-baratan atau westernisasi.

Pengaruh tersebut terjadi di masyarakat secara nyata saat ini dalam berbagai bidang kehidupan di antaranya yaitu; Pengaruh Ilmu dan Teknologi, Ilmu pengetahuan dan Teknologi mempunyai peranan penting dalam kehidupan dewasa ini, suatu bangsa akan maju dan berkembang jika memiliki ilmu pengetahuan dan teknologi yang mumpuni. Perkembangan ilmu pengetahuan ini terjadi dalam berbagai sektor industri, mulai dari pertanian, pertahanan, ekonomi, kedokteran, dan lain sebaginnya.

Perkembangan ilmu dan teknologi di dunia Barat terjadi dengan begitu pesatnya, kadang-kadang jauh melampaui nilai manfaat dan kegunaannya bahkan nilai kemanusiaan dan lingkungan. Penciptaan industri batu bara dan perminyakan dengan mengabaikan kerusakan lingkungan, penemuan-penemuan di bidang meliter seperti 
bom atom berdampak sangat luas tidak saja terhadap manusia itu sendiri tetapi juga terhadap lingkungan.

\section{B. Melestarikan Identitas Nasional}

Identitas nasional pada hakikatnya adalah manisfestasi nilai-nilai budaya yang tumbuh dan berkembang dalam aspek kehidupan satu bangsa (nation) dengan ciri-ciri khas, dan dengan ciri-ciri yang khas tadi suatu bangsa berbeda dengan bangsa lain dalam kehidupannya. Dalam hal ini adalah bangsa Indonesia dengan berbagai macam nilai luhur budayanya. Nilai-nilai budaya yang berada dalam sebagian besar masyarakat dalam suatu negara dan tercermin di dalam identitas nasional bukanlah barang jadi yang sudah selesai dalam kebekuan normative dan dogmatis, melainkan sesuatu yang terbuka yang cenderung terus menerus berkembang termasuk di era revousi industri 4.0. Karena keinginan untuk menuju kemajuan yang dimiliki oleh masyarakat Indonesia.Lebih lanjut bahwa konsepdari identitas nasional adalahsebuah konsep yang multidimensional dimana dikembangkan dan dianalisis oleh berbagai disiplin ilmu dan relevan dengan berbagai bidang penelitian.

Identitas Nasional merupakan salah satu bentuk dari identitas sosial. Identitas Nasional dianggap sebagai konsep utama dari identifikasi individu pada kelompok sosial dalam dunia modern, kedekatan anggota kelompok terhadap Negara mereka diekspresikan dengan rasa memiliki, cinta, loyalitas, kebanggaan, dan perlindungan terhadap kelompok dan tanah airnya. Hal tersebut yang menjadikan sebuah negara mempunyai identitas dan nilai-nilai tersendiri dalam menghadapi berbagai macam tantangan di era revolusi industri 4.0 yang semakin kompleks, utamanya dalam bidang pendidikan di Indonesia. Unsur-unsur dalam pembentukan identitas nasional sendiri adalah suku bangsa, komposisi etnis, agama, kebudayaan daerah dan bahasa pemersatu atau bahasa nasional. Terintegritasnya pendidikan multikultural dan identitas nasional secara benar, diharapkan mampu menanamkan nilai-nilai keberagaman, toleransi serta membangun generasi muda yang kompeten tanpa meninggalkan nilai-nilai luhur budaya Indonesia untuk menghadapi tantangan-tantangan utamanya dalam bidang pendidikan di Indonesia yang mengalami perkembangan ilmu pengetahuan dan teknologi di era revolusi industri 4.0 yang semakin maju. 
Untuk mengatasi berbagai tantangan dan permasalahan pendidikan di Indonesia era revolusi industri 4.0, pengintegrasian pendidikan multikultural dengan identitas nasional dapat dilakukan dengan cara berikut ini:

1) Integrasi pendidikan multikultural dengan berbasis local wisdomdalam desain kurikulum. Maka pendekatan multikultural untuk kurikulum diartikan sebagai suatu prinsip yang menggunakankeragaman kebudayaan peserta didik dalam mengembangkan filosofi, misi, tujuan, dan komponen kurikulum, serta lingkungan belajar sehingga siswa dapat menggunakan kebudayaan pribadinya untuk memahami dan mengembangkan berbagai wawasan, konsep, keterampilan,nilai, sikap, dan moral yang diharapkan. Teori belajar dalam kurikulum multikultural yang memperhatikan keragaman sosial, budaya, ekonomi, dan politik tidak boleh lagi hanya mendasarkan diri pada teori psikologi belajar yang bersifat individualistik dan menempatkan siswa dalam suatu kondisi value free, tetapi harus pula didasarkan pada teori belajar yang menempatkan siswa sebagai makhluk sosial, budaya, politik, dan hidup sebagai anggota aktif masyarakat, bangsa, dan dunia.

2) Optimalisasi pendidikan kewarganegaraan dalam upayanya memperkuat identitas nasional dengan berlandaskan multikultural dan local wisdomyang dimiliki oleh bangsa Indonesia.

3) Penempatan pendidikan multikultural sebagai filosofi pendidikan, pendekatan pendidikan, bidang kajian dan bidang studi. Penempatan pendidikan multikultural sebagai falsafah pendidikan memiliki arti bahwa pandangan terhadap kekayaan keberagaman budaya Indonesia hendaknya dimanfaatkan sebaik-baiknya untuk mengembangkan dan meningkatkan sistem pendidikan dan kegiatanbelajar-mengajar di Indonesia. Pendidikan multikultural sebagai pendekatan pendidikan berarti penyelenggaraan dan pelaksanaan pendidikan yang kontekstual dan memperhatikan keragaman budaya Indonesia. Pendidikan multikultural sebagai bidang kajian dan bidang studi berarti disiplin ilmu yang dibantu oleh sosiologi dan antropologi pendidikan untuk menelaah dan mengkaji aspek-aspek kebudayaan, terutama nilai-nilai budaya dan perwujudannya untuk atau dalam penyelenggaraan dan pelaksanaan pendidikan. 
Melalui penanaman nilai-nilai pendidikan multikultural yang benar, diharapkan generasi muda Indonesia yang merupakan penerus bangsa mampu menjawab berbagai tantangan pendidikan di era revolusi industri 4.0. Membentuk generasi muda yang kreatif, inovatif, berkarakter,berintegritas dan menjunjung tinggi toleransi sesuai dengan nilai-nilai identitas nasional sebagai bangsa Indonesia dengan segala keanekaragaman budayanya. 


\section{BAB III}

\section{PENUTUP}

\section{A. Kesimpulan}

Keadaan meniru-niru yang terdapat dalam dunia Barat. Atau dengan kata lain westernisasi menjadikan kita orang Barat yang berkebudayaan Barat. di sisi lain, sikap para peniru yang merendahkan adat, budaya dan bahasa nasional. Pola adopsi ini tidak saja terjadi secara objektif, namun bisa terjadi secara subjektif yaitu interaksi yang lahir dari ide suatu individu, masyarakat atau bangsa untuk mengambil dan meniru cara-cara orang Barat dalam berbagai demensi untuk suatu tujuan ke arah kemajuan. Faktor yang mempengaruhi timbulnya westernisasi di Indonesia secara umum disebabkan oleh faktor informasi dan yang datangnya melalui audio visual, disamping itu juga melalui kontak sosial terutama sekali di daerah-daerah pusat industri dan kepariwisataan. Kemajuan-kemajuan yang sangat besar dalam bidang komunikasi menyongsong timbulnya era informasi secara global, artinya tidak ada satu bangsapun di dunia ini menutup diri dari era informasi.

Identitas nasional sendiri pada hakikatnya adalah manisfestasi nilai-nilai budaya yang tumbuh dan berkembang dalam aspek kehidupan satu bangsa Penempatan pendidikan multikultural sebagai filosofi pendidikan, pendekatan pendidikan, bidang kajian dan bidang studi. Pendidikan multikultural sebagai bidang kajian dan bidang studi berarti disiplin ilmu yang dibantu oleh sosiologi dan antropologi pendidikan untuk menelaah dan mengkaji aspek-aspek kebudayaan, terutama nilai-nilai budaya dan perwujudannya untuk atau dalam penyelenggaraan dan pelaksanaan pendidikan. Membentuk generasi muda yang kreatif, inovatif, berkarakter,berintegritas dan menjunjung tinggi toleransi sesuai dengan nilai-nilai identitas nasional sebagai bangsa Indonesia dengan segala keanekaragaman budayanya.

\section{B. Saran}

Kami menyadari bahwa masih banyak kekurangan dalam penulisan makalah ini. Oleh karena itu, kritik dan saran yang bersifat membangun selalu kami harapkan demi perbaikan dan kesempurnaan makalah kami. Dan semoga makalah ini dapat dijadikan sebagai sarana yang dapat mendorong Mahasiswa untuk bisa berfikir aktif dan kreatif. 


\section{DAFTAR PUSTAKA}

Anis, M. Z. A. (2016). Sejarah, Kesadaran Sejarah dan Pupusnya Identitas Nasional.

Rohman, A., \& Ningsih, Y. E. (2018, October). Pendidikan multikultural: penguatan identitas nasional di era revolusi industri 4.0. In Prosiding Seminar Nasional Multidisiplin (Vol. 1, pp. 44-50).

Suharni, S. (2015). Westernisasi Sebagai Problema Pendidikan Era Modern. Jurnal AlIjtimaiyyah, 1(1). 